\title{
IDENTIFYING MATERIAL, GEOGRAPHICAL AND INSTITUTIONAL MOBILITIES IN THE GLOBAL MARITIME TRADE SYSTEM
}

This is the pre-published version of the text. The final published chapter can be found in:

Monios, J., Wilmsmeier, G. (2015). Identifying material, geographical and institutional mobilities in the global maritime trade system. In: Cargomobilities: moving materials in a global age. Ed: T. Birtchnell, S. Savitzky, J. Urry. Routledge: Abingdon. pp. 125-148.

\author{
$\mathrm{JASON} \mathrm{MONIOS}^{1} \uparrow$ and GORDON WILMSMEIER $\uparrow \dagger$ \\ $\dagger$ Transport Research Institute, Edinburgh Napier University, Merchiston Campus, \\ Edinburgh EH10 5DT, United Kingdom \\ j.monios@napier.ac.uk \\ †† UNECLAC, Av. Dag Hammarskjold 3477, Vitacura, Santiago, Chile \\ Gordon.wilmsmeier@cepal.org
}

\section{Introduction}

Economic development has traditionally been associated with a transformation of material mobility, which is defined for the purposes of this chapter as the physical movement of materials. The quantity of this movement exploded in the wake of the development of containerised transport in the second half of the twentieth century, whereby the adoption of the maritime container revolutionised the geography of the global maritime logistics system. The globalisation of trade has since grown at a furious rate, changing the structure of trade and shifting the relations of industrial and institutional integration.

Liner shipping strategies based on hub-and-spoke and hierarchical network structures have led to a concentration of container traffic at selected ports. In recent years, the attempt to manufacture strategic locations by engendering centrality and intermediacy has emerged as a recurring issue among actors in secondary ports as well as in greenfield developments, as

\footnotetext{
${ }^{1}$ Author for correspondence.
} 
local and regional actors fear being "driven" into peripherality as a result of this concentration. The effects of path dependence and the contingency of both private investment and public planning approval have been found to play important roles in this process.

This chapter explores the evolution of maritime networks and the "autopoietic" nature of port development as ports pursue a variety of proactive and reactive strategies that involve different actors within a complex institutional environment. The physical immobility of transfer points in which global mobility is embedded masks an institutional mobility, as ports are not simply physical spaces but complex organisations with varying levels of public and private ownership, goals and responsibilities. The institutional adaptations of port actors in recent years enables identification of both geographical and institutional mobility, which builds on previous theoretical work by corresponding to the geographical and institutional kinds of proximity identified by Hall and Jacobs (2010) and the geographical and institutional kinds of peripherality identified by Monios and Wilmsmeier (2012b).

The challenges of "unproductive" and "induced" mobilities in the maritime system are also identified and discussed in this chapter. Finally, a systems perspective is applied in order to develop a framework mapping the complexity of elements and flows in material mobilities. The discussion of these findings raises questions about both public and private sector responses to the structurally changing and geographically shifting maritime geography of trade. The findings deepen understanding of the recursive relationship between the mobile (shipping networks) and the immobile (ports), providing tools to understand the spatiotemporal evolution of maritime freight mobility.

\section{Understanding categories of mobility}

The central concerns of mobilities research, "of too little movement or too much, or of the wrong sort or at the wrong time" (Sheller \& Urry, 2006, p.208), are fundamental to an understanding of the maritime freight transport sector. Global container flows are comprised not just of trade between countries but a large proportion of interchange movements as well as the movement or "repositioning" of empty containers, all of which increase both transport and management costs. Figure 1 shows total container handlings at world ports, divided into full and empty, as well as the percentage of empty movements and transhipment. 


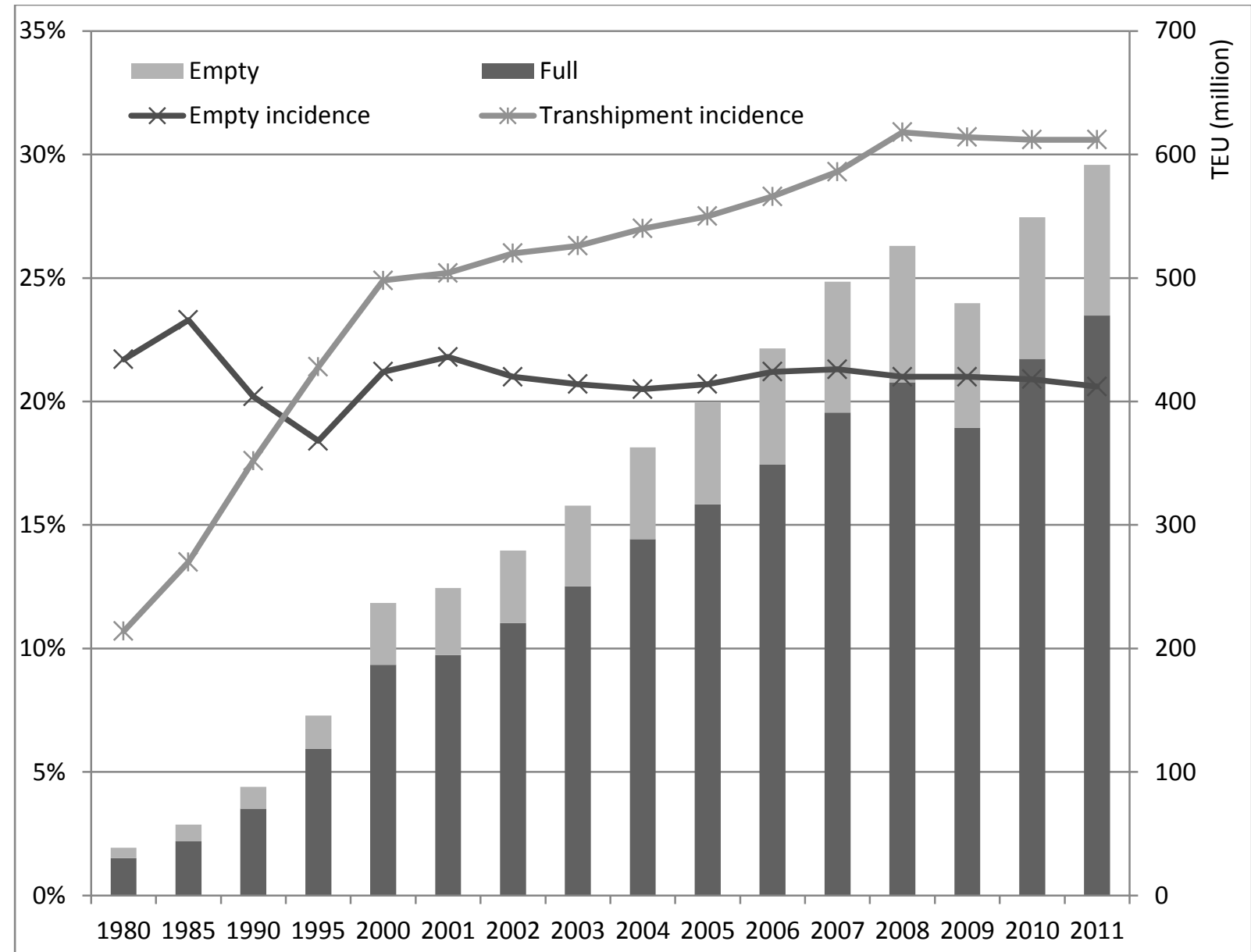

Figure 1 Loaded and empty container movements as shares in total world container movements

Source: authors, based on Drewry (2012a)

The figure shows that the number of empty container handlings has risen at a similar rate to total container handlings in ports, meaning that the overall percentage has changed little in the last decade. By way of example, almost two millions containers full of British air are exported every year, traded with the Far East for containers full of goods. Containers cost money to move, so the more empty or unproductive moves that take place, the higher the cost.

An example of such unproductive mobility can be found by looking at the case of the port of Grangemouth in Scotland. Figure 2 shows that, since 2006, the number of loaded inbound containers has decreased by over $30 \%$ or 43,000 TEU. Likewise, the number of empties imported has risen by 40,000 TEU, almost the same amount. 


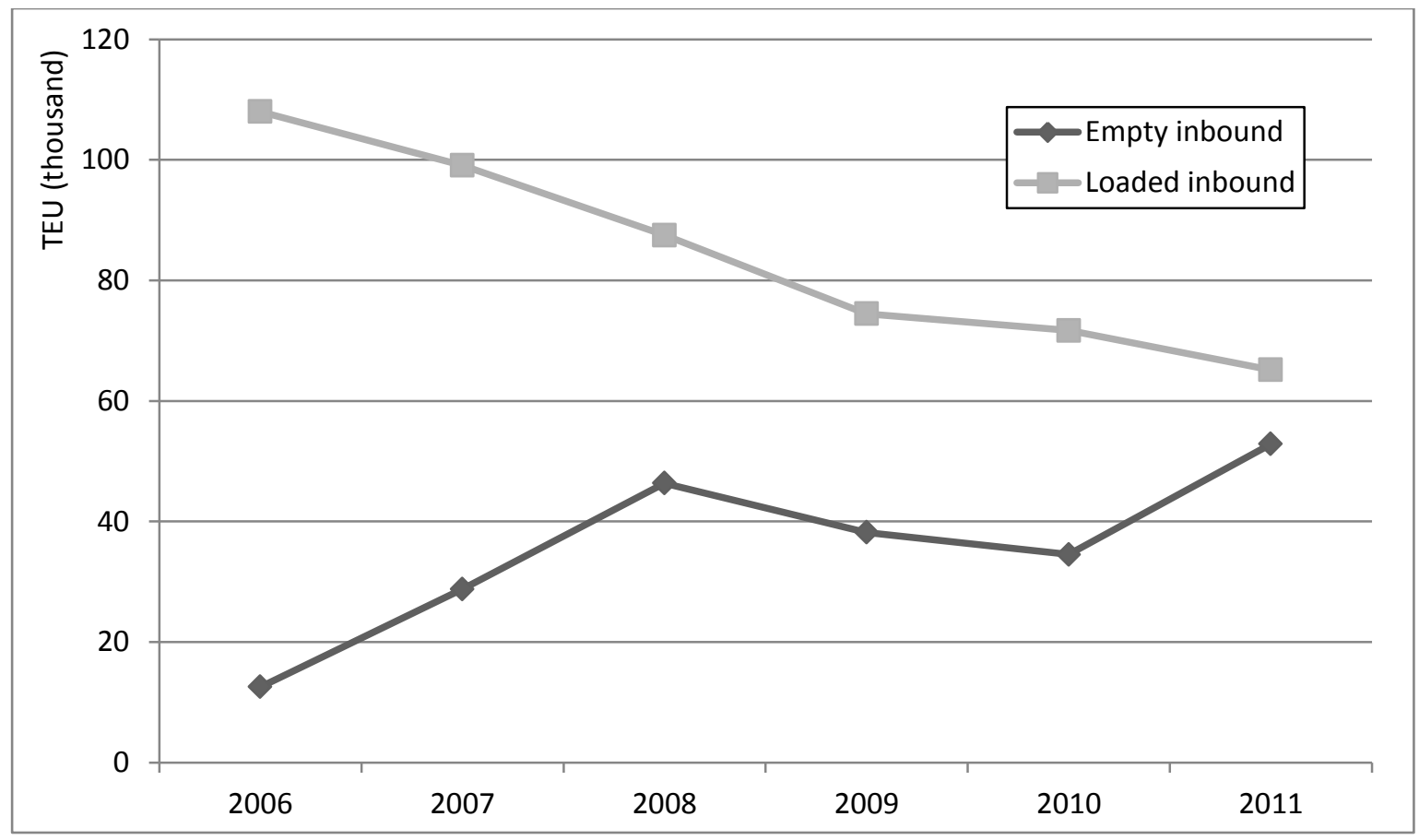

Figure 2. Inbound containers at Grangemouth 2006-2011

Source: authors, based on DfT (2012)

The example reveals the relationship between a decline in containerised imports (in this case because Scottish imports are being moved through English ports then trucked north in articulated lorries) and the requirement to reposition empty containers for local exporters, thus incurring an additional cost which reduces the competitiveness of these shippers (for details on the Scottish case see Roser et al., 2013).

The second interesting statistic from Figure 1 is the increasing incidence of transhipment, meaning that in $201130.6 \%$ of container handlings at world ports were not genuine trade but containers being transhipped as part of a hub-and-spoke strategy, where cargo from smaller ports is transported to large hubs and transhipped onto very large vessels that then traverse the main line route between the hub ports. These two findings (empty movements and transhipments) can be defined as examples of unproductive and induced mobility, respectively. Thus the search for greater economies of scale and density through hub-andspoke strategies results in unproductive and induced mobility.

Beyond the movement of empty units, ship capacity utilisation is a second source of unproductive mobility. However, very few statistics exist exploring capacity utilisation under hub-and-spoke strategies and whether unproductive mobility is increasing or decreasing on shipping routes. A recent study from Wilmsmeier and Parushev (2014) showed that capacity utilisation on the main trade routes serving the East Coast of South America was as little as 
$40 \%$ in some periods between 2000 and 2012. This problem is exacerbated by the emergence of ever-larger container vessels on mainline routes (see Figure 3), resulting in the cascading of vessels down to other routes which may not require such large ships.

A differentiation between productive, unproductive and induced mobilities is essential to an understanding of material mobility. Furthermore, the relation and interaction between immobile and mobile infrastructures necessitated by mobility (see Sheller \& Urry, 2006; p.219) requires further exploration. Just as the immobility of ports and airports underpins the mobility of people and goods, the unproductive mobility in container shipping manufactures new relations and influences decisions relating to productive mobility, as industry actors strive to minimise unproductive mobility. For instance, a manufacturer may relocate close to a hub port in order to reduce transport distance and increase the availability of empty containers. Such complex systems create further unproductive mobility in the form of time mobilities, or induced waiting. While passengers spend much of their "travelling" time waiting at airports, containers spend days waiting at ports. Ports and shipping lines strive to reduce this dwell time by levying charges but a certain level of slack in the system is inevitable.

It has been estimated that there exist about three containers for every container slot in the world fleet, to account for overland movements as well as taking up the slack in the system (Rodrigue, 2013). In 2008, at the peak of world container shipping just before the recession, there were about 28 million TEU of containers in existence (UNCTAD, 2009). Most of these are controlled by shipping lines, either through ownership or by leasing them from container leasing companies, who provide flexibility for shipping lines who do not want to take the risk of purchasing too many containers. Shipping lines own approximately $62 \%$ and the remaining $38 \%$ is owned by leasing companies (Theofanis \& Boile, 2009).

Unproductive mobility is also reflected in the movement of ballast water around the globe, which is water held in storage tanks to stabilise empty or minimally loaded vessels. This transport of water across water is a necessary part of maritime trade in order to cope with imbalances, but what is traded is not goods between distant countries but an almost invisible mobility of marine life forms, that are part of visible mobilities. Like undocumented and unaccounted human immigrants using containers to cross national borders, marine life forms are now being scrutinised to determine if they will be allowed to enter new territorial waters, and regulations are being developed to manage this process. 
To take this point even further, one could consider the mobility of seafarers, crossing the globe but rarely leaving the ship (in stark comparison to the weeks in port experienced by sailors in the days of pre-containerised maritime trade). Seafarers are more mobile than most people in the world but simultaneously immobile as they rarely leave the ship, have few rights and can even be stranded, through piracy or bankruptcy or even sometimes the simple negligence of the shipping line employing them. Cases exist of such employees being left with no money and food, but unable to enter the country where they happen to be stranded, with no rights, papers or prospects of returning home. Such essential workers in the maritime industry have no control over their mobility (either simple physical mobility or mobility in the sense of legal entry to a country or ability to secure employment), even as it is necessary to permit the mobility of maritime trade.

This raises another important aspect of mobilities, which is the differential in access between developed and developing countries in access to flights, travel, trade and other essential mobilities of modern life. This is also true in maritime trade, in which peripheral ports and regions with poorer and more expensive access are disadvantaged. This is exemplified by the existence of pure transhipment hubs where freight congregates then moves on but never actually leaves the port to enter the country. Thus a poor region may have huge amounts of trade massing on its doorstep while obtaining little benefit for its own economy. For example, $99.0 \%$ of the $1.1 \mathrm{~m}$ TEU handled at Freeport in the Caribbean and $95.6 \%$ of the $2.3 \mathrm{~m}$ TEU handled at Marsaxlokk in Malta are transhipped. So there is little access to the economic benefits of mobility that these ports facilitate for the distant regions utilising these transhipment ports. The port of Gioia Tauro in Italy has received large public subsidies in order to develop economic activity in the poor south of Italy but the port has remained almost exclusively a transhipment port (94.0\%), due to a variety of industrial and institutional factors. This reflects tensions between relational and territorial power, as discussed by Amin: "local advocacy . . . must be increasingly about exercising nodal power and aligning networks at large in one's own interest, rather than about exercising territorial power" (2004; p.36).

Other political factors both enabling and limiting mobilities can be seen in an analysis of global shipping routes. Geographical limitations direct container ships through a relatively fixed number of bottlenecks across the globe, some natural (e.g. the Malacca Straits), some constructed (e.g. the Panama and Suez Canals). Political disagreements have caused blockages at the Suez Canal in the past, while other political imperatives have directed the 
expansion of the Panama Canal, as well as a competing project recently begun in Nicaragua. The Northern Sea Route, linking Europe and the Far East along the top of Russia is becoming physically accessible due to melting ice, but many challenges must be resolved before this route can become a major artery of global maritime trade.

Mobility may be measured in terms of distance covered and quantities transported. In the case of people, this is passenger $/ \mathrm{km}$ and for materials ton $/ \mathrm{km}$. Such measurements do not tell the whole story, as they do not include the share of unproductive or induced mobility, as identified above, nor do they consider the physical immobility of transfer points embedding global mobility, which also masks an institutional mobility, to be considered later in this chapter.

In summary, maritime mobilities take various forms, each influencing and influenced by several underlying processes. This section has identified productive, unproductive and induced mobilities in the maritime sector, while also raising the importance of understanding the nature of the immobile transfer points facilitating global mobility. The following sections will explore some of these processes in more detail, such as concentration, centralisation and integration.

\section{Port system evolution}

Understanding the evolving role of ports and their relation with elements of the maritime system is vital from a strategic perspective as port infrastructure enables mobility and thus partly defines its tempo and rhythm. Numerous studies on port system development exist, evolving from the traditional spatial analyses of port expansion and upgrading of berthing and handling facilities (Bird, 1963; Taaffe et al., 1963; Rimmer, 1967; Hoyle, 1968; Hayuth, 1981; Barke, 1986; Van Klink, 1998) to the more recent focus on port competition through hinterland accessibility, such as the concept of port regionalisation as one possible pathway in port system evolution (Notteboom and Rodrigue, 2005; Monios and Wilmsmeier, 2012a; Monios \& Wilmsmeier, 2013). Other work focuses on competition in the maritime foreland (as argued by Sanchez and Wilmsmeier, 2006), examining the role of intermediate transhipment hubs and the structure of maritime services (Rodrigue and Notteboom, 2010).

A wave of consolidation swept the industry in the decade leading up to the onset of the global economic crisis in 2008, in which many mergers and acquisitions took place in both shipping liner services and port terminal operations (Slack \& Frémont, 2005; Notteboom, 2007; Song \& Panayides, 2008; Van de Voorde \& Vanelslander, 2009). In 2012, the top ten 
carriers controlled approximately $63 \%$ of the world container shipping capacity (Alphaliner, 2012), while the top ten port terminal operators handled approximately 36 per cent of total container throughput (of which 26.5 per cent was just the top four), measured in "equity TEU" (Drewry, 2012b). ${ }^{2}$

Wilmsmeier and Notteboom (2011) captured this port system evolution in a four-phase generic model:

First phase. The liner shipping network is determined by point-to-point direct services with a strong local or regional orientation. The liner service network is highly regional in orientation and interconnectivity to the overseas markets is poor. Government involvement in the port sector is typically high while at the same time international market players (shipping lines and terminal operators) face limited possibilities to enter the region;

Second phase. The region and the market players seek a higher connectivity to overseas markets by consolidating cargo in an intermediate hub. The first tendencies towards a huband-spoke network emerge. The evolving liner service network configuration increases the dependency of the port system on indirect services via the hub, while direct regional services start to lose their importance. The growing connectivity of the port system to overseas markets increases the region's attractiveness to shipping lines and international port operators. The rising pressure on port infrastructures and the need for a professional and commercial approach to market dynamics urges government bodies to revise their port policy. Often, the local/regional/national government will seek the start-up of a port devolution process to face the mounting infrastructural and operational port challenges linked to the opening up of the region to the world market. The resulting changes in the port governance and policy framework enable international stevedoring groups and shipping lines to access key assets in the local ports and to seek control over terminal operations.

Third phase. Port traffic growth leads to a further outreach of the hub-and-spoke network and the inclusion of new ports in this pattern. International port operators further penetrate the market and state intervention in ports is strongly reduced. Main lines are growing and smaller regional services start to develop again in a secondary network.

\footnotetext{
${ }^{2}$ The "equity TEU" concept was devised by Drewry as a more accurate way than simple TEU throughput to account for the fact that some terminal operators have shares in each other.
} 
Fourth phase. The market size of specific ports has grown to such an extent that shipping lines can now offer direct services from these ports to overseas regions. The hub sees its functional position undermined. In view of maintaining its role in the network, the hub will seek liner service connections to smaller ports in the region which still lack connectivity to overseas market. Consequently, the terminal activity in the hub shifts in geographical terms and a new secondary hub-and-spoke network emerges involving other gateway ports.

\section{Concentration and deconcentration}

The four-stage model of Wilmsmeier and Notteboom (2011) tracks the geographical concentration of cargo flows at hub ports and a later trend of geographical deconcentration as other ports grow and compete. The geographical concentration of cargo from a shipping line and port operator perspective has clear benefits of granting economies of scale and density (see also Cullinane and Khanna, 1999) and thus the combination of these strategies with exploiting geographically favourable locations might lead to a level of port concentration that has severe repercussions on the port hinterland and the port system as a whole, if not counteracted by proactive policies and public sector strategies.

As a port system moves towards concentration, particularly for unitised cargo, ${ }^{3}$ significant challenges to hinterland infrastructure become apparent. Ducruet et al. argued that "concentration stems from the path-dependency of large agglomerations", while drivers of deconcentration include "new port development, carrier selection, global operation strategies, governmental policies, congestion, and lack of space at main load centres" (2009; p.359). According to Barke (1986) and Hayuth (1981), port system concentration will eventually reach its limits and invert, leading to a process of deconcentration, a phenomenon discussed more recently by Slack and Wang (2002), Notteboom (2005), Frémont and Soppé (2007) and Wilmsmeier and Monios (2013). However, existing theory falls short of differentiating between deconcentration that emerges upon failure of a system in a reactive manner, deconcentration that materialises from proactive port development strategies, and deconcentration that emerges from new economic and industrial development. Thus the drivers of deconcentration processes can be related not only to the port system, but also to the transport system (e.g. hinterland infrastructure and carrier strategy) and the economic system

\footnotetext{
${ }^{3}$ Unitised cargo refers to cargo moved in a container rather than transported loose, as in bulk shipping.
} 
(e.g. logistics strategies, economic development) (Wilmsmeier and Monios, 2013; Sanchez and Wilmsmeier, 2010; Robinson, 2002).

Recent empirical research has identified the emergence of secondary ports as a key factor of port system evolution (Wang \& Ng, 2011 - China; Wilmsmeier \& Monios, 2013 - UK; Wilmsmeier et al., 2014 - Latin America). Such secondary ports are following expansion plans to reposition themselves as second-tier regional hubs. This means that, rather than small ports accessing global trade via large hub ports, some medium-sized ports are attempting to insert themselves as intermediate hubs, whereby small feeder vessels connect small and medium ports, while large feeder vessels connect medium and hub ports, then the new generation of ultra-large container vessels connect the hub ports. Such second-level hubs also continue to serve their immediate region, meaning they have a healthy mix of transhipment and gateway traffic on which to secure their business development. Another common feature of secondary ports is that they often engage in more integrated development strategies that also include the consideration of logistics development connected to the port.

The introduction of larger vessels on the world's mainline routes can be expected to initiate a process whereby vessels cascade down to other trades. For example, when new 18,000 TEU vessels are introduced on the high demand Asia-Europe route (currently served by vessels averaging around 11,000 TEU capacity), the smaller vessels that had been serving that route (around 8,000 TEU) will be moved on to the next highest demand trade route, and so on. This means that the smallest vessels serving small ports will eventually be phased out, so the smallest size of vessel will increase, and recent research has suggested that potentially similar results may be expected even in very different regions. In the UK, feeder routes linking regional UK ports with transhipment hubs (either UK or continental ports) may in future be served by larger vessels in the range of 2,000-4,000 TEU, which would mean some regional ports have insufficient handling capacity to accommodate them (Wilmsmeier and Monios, 2013). Such a situation would support the growth of regional second-tier hubs, as identified above, which can then serve the smaller ports either by smaller feeders or even land transport (thus raising issues relating to the quality and capacity of hinterland infrastructure links). A similar issue is found in Latin America, albeit on a much larger scale. A recent study expects that 13,000 TEU ships will start to call regularly on the coasts of South America between 2016 and 2020 (Sánchez and Perrotti, 2012), which will have direct implications for the liner shipping networks and port infrastructure in the region. 


\section{Centralisation and decentralisation}

As a result of these changing industry dynamics, ports evolved from city-based centres of local trade to major hubs for cargo to pass through, with distant origins and destinations. This development was driven to a large degree by the container revolution, as distribution centres located in key inland locations became key cargo generators and attractors. Port hinterlands began to overlap as any port could service the same hinterland. Another key factor was increased economies of scale available from ever-increasing ship size (see Figure 3).

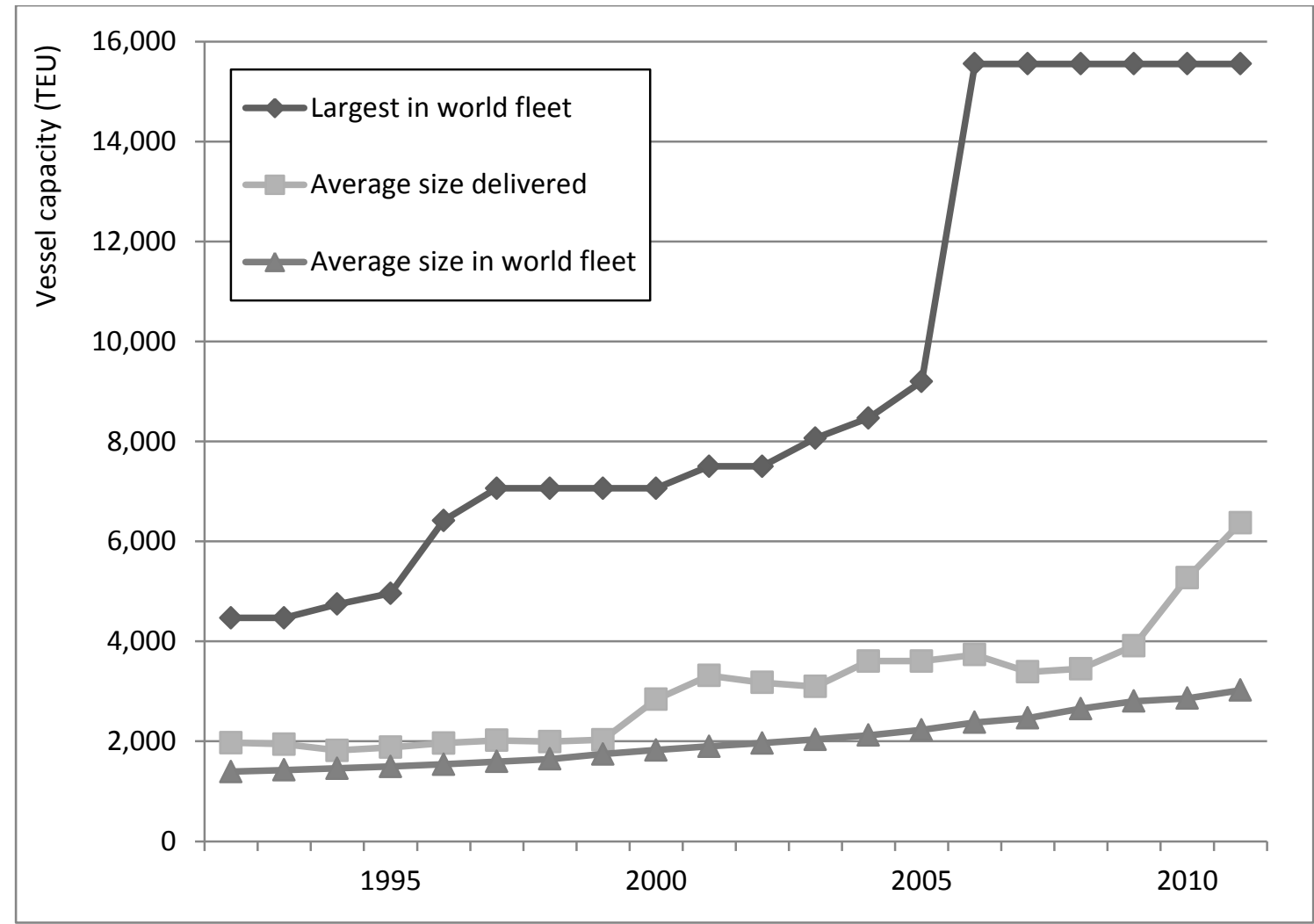

Figure 3. Container ship size progression 1992-2011 (TEU capacity)

Source: authors, based on Drewry (2012a)

The figure shows that the average size of new vessels delivered in 2012 almost matches what was the largest container vessel in service only ten years ago.

Container ports expanded out of origins as general cargo ports, or were built entirely from scratch. Some existing major ports today show their legacy as river ports and require dredging to keep pace with larger vessels with deep drafts (e.g. Hamburg), whereas newer container ports are built in deep water, requiring not dredging but filling in to create the terminal land area (e.g. Maasvlatke 2, Rotterdam). The move to purpose-built facilities with 
deeper water severed the link between port and city, with job numbers reduced and those remaining moved far from the local community, altering the economic geography of port cities (Hesse, 2013; Martin, 2013).

The severance between the port and the city was followed by a similar rupture between inland freight handling centres and their city locations. Hesse (2008), drawing on Amin and Thrift (2002), identified new "geographies of distribution", remarking that "the freight sector reveals an astonishing degree of disconnection of logistics networks from traditional urban and economic network typologies" (p.29).

Centrality can be derived from the German school of location theory (Von Thünen, 1826; Weber, 1909; Christaller, 1933; Hotelling, 1929; Lösch, 1939), in which the centre is the marketplace and location of important administrative and government activities, exhibiting a centripetal pull on the region, while intermediacy refers to an intermediate location in between such centres. From a transport perspective, Fleming and Hayuth (1994) observed how central locations are often also intermediate, acting as gateways to other locations. They added that such locations can be manufactured, depending not solely on natural geographical endowments, but on commercial or administrative decisions (see also Swyngedouw, 1992). $\mathrm{Ng}$ and Gujar (2009) discussed centrality and intermediacy as determining concepts of inland nodes and how they can be affected by government policy.

The German school of location theory takes an economic approach to such discussions, leading into regional science, which tends to treat transport as a demand derived from centrality and intermediacy. The notion of transport solely as a derived demand has, however, been challenged and reformulated as an integrated demand (Hesse \& Rodrigue, 2004; Rodrigue, 2006; Panayides, 2006). The planning of logistics processes influences transport requirements but they are themselves influenced by the location and quality of transport nodes and corridors. States at all levels are under increasing pressure to provide an attractive entrepreneurial culture to draw increasingly mobile global capital flows, and local and regional authorities attempt to secure these flows through strategies of clustering and agglomeration. Monios and Wilmsmeier (2012b) demonstrated how temporary "scalar fixes" (Brenner, 1998) such as the spread of political authority between countries, regions and cities are based on temporary "spatial fixes" (Harvey, 1981, 1982) such as physical regional boundaries and planning jurisdictions). These boundaries change over time, thus their influence and authority exhibit both territorial and relational aspects. From a transport infrastructure perspective, the attempts by states at any scale (local, regional or national) to 
harness global capital flows through the proxy of container flows result in spatial fixes such as ports and intermodal terminals. These physical spaces then exert a decades-long legacy impact on the structure of logistics and transport systems, even as temporary scalar fixes continue to evolve.

Challenging path dependency and overcoming peripherality are key issues examined in the literature, although disagreement remains over the extent to which these actions can be engineered through public policy. A further question is which level of government should direct these policies, further complicated by changing roles of the public and private sector in the provision of transport infrastructure (Hall et al., 2006). As a result of national and

supranational policy promoting intermodal transport, poorly-connected regions can receive large sums of money towards freight infrastructure projects, but expected traffic does not always materialise, threatening goals of both emissions reduction from modal shift and economic growth through logistics expansion. Previous research has examined the economic impact of regional development policy in the European Union (e.g. Rodríguez-Pose \& Fratesi, 2004) and Ezcurra and Rodríguez-Pose (2013) highlighted the difficulty in measuring the link, if one exists, between decentralisation of political power and a change in economic performance. A strategy conflict arises because much European funding for transport projects is aimed at reducing emissions but is actually pursued by local and regional bodies which desire economic benefits from logistics development (Monios, 2015).

\section{Port competition and hinterland capture}

As seen above, strategies of port competition vary between primary and secondary ports and each influences the other. Strategies include major port expansions to attract larger ships, reorganisation of the port yard including automation to improve efficiency and increased integration with landside links.

In the past decade, shipping lines and port terminal operators have consolidated and integrated their portfolios through mergers and acquisitions, resulting in a small number of dominant firms. These firms have since benefited from significant economies of scale and scope and enabled them to provide something of a seamless intermodal transport movement from port to port. Many actors are endeavouring to pursue this same trend inland, but for true intermodality to be successful and economically feasible, land transport operations require a similar level of consolidation to that of the sea leg. The different characteristics of land transport, however, challenge this goal. As Graham wrote: "the land-side is characterised by 
relatively low investment, high operating expenses, little scale incentive to collective operation and a considerable level of unremunerated activity requiring cross payment out of sea freight" (1998; p.135); fifteen years later, this statement remains true and explains both why port actors want to control hinterland links, and why it remains so difficult.

Inland terminals and corridors can be developed in the hinterland according to different strategies, involving differing motivations, actors, functions and logistics models. They can be close to the port, mid-range or distant. They can be built to ease port congestion or for reasons of hinterland capture and port competition. They can be developed by port authorities, port terminal operators and transport providers such as rail operators or thirdparty logistics providers (3PLs), or they can be developed by public bodies, whether national, regional or local. They can be designed on a rail-based strategy of generating economies of scale on high-capacity, long-distance links. By contrast, they can be road-based shortdistance satellite terminals to ease port congestion or facilitate fast-track customs clearance.

Academic literature over the past decade has begun to develop conceptual models to classify and analyse different strategies of inland terminal and corridor development (e.g. Rodrigue \& Notteboom, 2009; Roso et al., 2009; Bergqvist et al., 2010; Rodrigue et al., 2010; Monios \& Wilmsmeier, 2012). Wilmsmeier et al. (2010, 2011) borrowed from the terminology of industrial organisation (i.e. forward and backward integration) to introduce a conceptual approach to inland terminal development, contrasting Inside-Out development (land-driven e.g. rail operators or public organisations) with Outside-In development (seadriven e.g. port authorities, terminal operators). This approach identifies how different institutional frameworks reveal nuances in the different kinds of integration between inland terminals, logistics platforms, rail operators and seaports (Monios, 2014). This distinction is a shorthand way of identifying potential strategy conflicts between actors with different motivations. Ports invest in inland terminals to capture and control hinterlands as well as to push containers inland to alleviate port congestion, subject to the ability of the port terminal to act directly in rail operations through joint ventures or similar business models. Rail operators develop terminals and port shuttles for similar reasons, yet need to integrate international and domestic flows with different container and wagon requirements and other planning difficulties. Government agencies, whether local, regional or national develop terminals generally from business development motivations, therefore often include a logistics platform. The motivation of the port actors (whether port terminals or port authorities) are thus different to inland actors, and require complementary operational models 
in order to work successfully. Similarly, Hesse contrasted the local and regional interests and influence of city stakeholders with the regional, national and international focus of port actors: "the two different groups of stakeholders involved are quite distinct in their power and in their potentials to achieve their goals" (2013; p.40).

Wilmsmeier et al. (2011) argued that this differentiated perspective had not received sufficient attention in discussions of the port regionalisation concept. This model has since been used to aid disaggregation of regionalisation strategies and comparison of potentially conflicting strategies that may be pursued by terminals within a port or between ports within the same range. $\mathrm{Ng}$ and Cetin (2012) suggested that Inside-Out development is the common model in developing countries, as opposed to Outside-In in developed countries, whereas Monios and Wilmsmeier (2012a) showed that Inside-Out development is common in developed countries also. Increasing port competition in China has spurred several Outside-In developments there (Monios \& Wang, 2013).

While European and North American seaports are often considered to be increasingly integrated with their hinterlands (as per the regionalisation concept of Notteboom \& Rodrigue, 2005), the East Asian hinterland model is generally categorised as coastal concentration with low inland coverage (Lee et al., 2008). The sailing distances between pairs of Chinese ports within the same economic cluster are very short, resulting in significant hinterland overlap and intensified inter-port competition. Figure 4 demonstrates the emergence of the Chinese container port industry by addressing its growth in investment and container throughput since 2000. China's international trade value has also been included due to its high relevance to both economic growth and port traffic generation. Starting with a base level at the year 2000, the pace of investment growth in coastal port infrastructure shows a significant increase in relation both to the growth of container throughput and international trade value. Investment in 2011 reached US\$ 15.9 billion, which is about eleven times the total investment in 2000, while growth of the latter two categories was far behind this pace, increasing by a factor of about seven. 


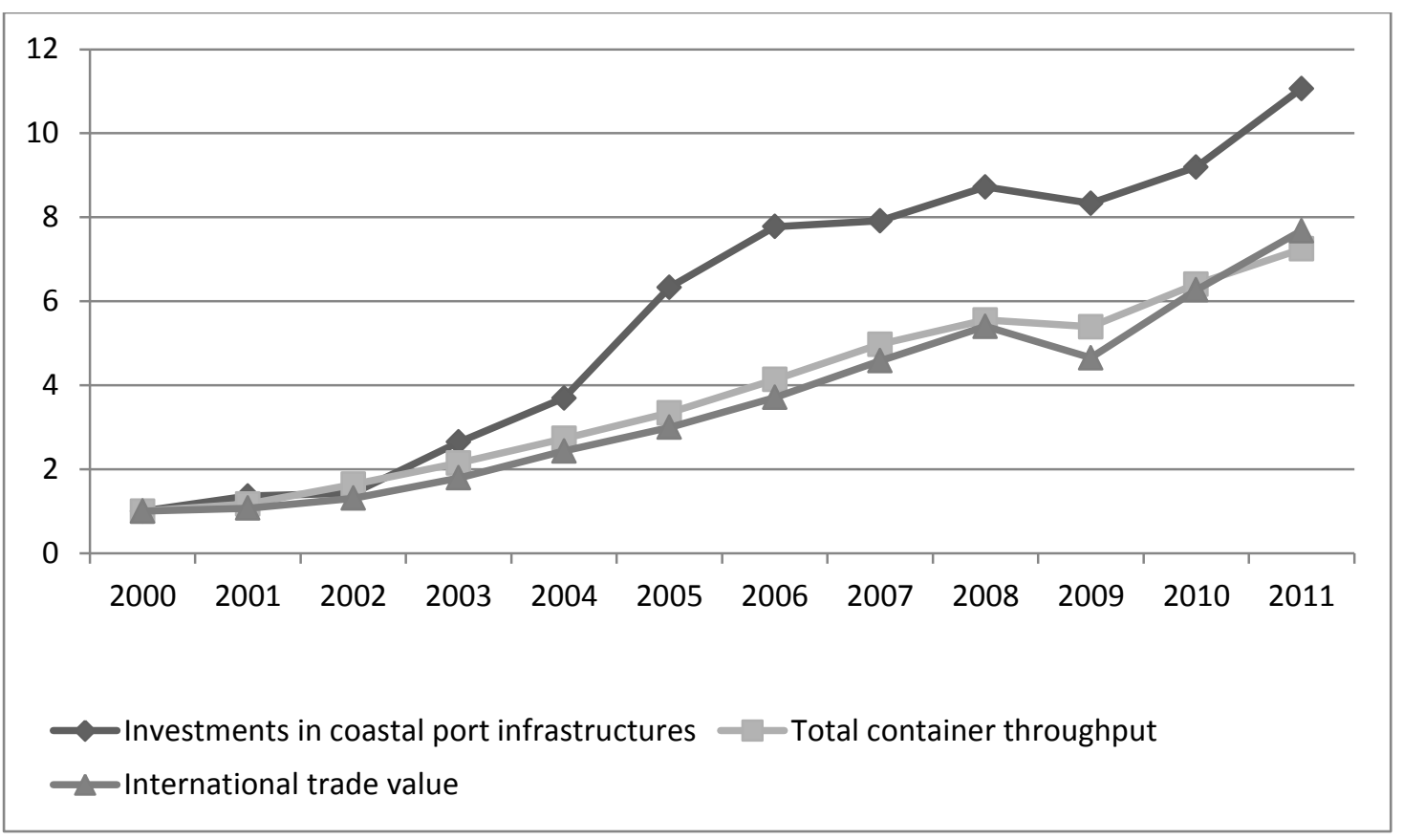

Figure 4. Comparison of container throughput, trade value and investment in China's container port industry

Source: Monios \& Wang (2013)

This surge in investment in port infrastructure over the last ten years, which was primarily intended to facilitate the expansion and improvement of cargo handling capacity, resulted in excessive inter-port competition. Cullinane and Wang (2012) argued that this investment may not be sustainable and could lead to an inefficient utilisation of port resources if the market environment were to change fundamentally. It is especially true for China as its exportoriented economy faces the simultaneous threats of a rapid rise in domestic labour cost and a contraction in global demand. It is therefore essential for port authorities and terminal operators to maintain their growth by securing traffic flows, balancing the dependency on exports and/or enhancing their hinterland supply. Monios and Wang (2013) argued that the latter would be an easier and more efficient choice, which goes some way towards explaining the observed strategy since 2002 of major Chinese ports investing in inland terminals.

\section{Institutional adaptation: autopoiesis and recursion}

Recent research has shown that some port actors have expanded their institutional capacity beyond their core competency of container handling, as a reaction to some of the problems identified in the previous sections. Such institutional developments include restructuring business models through processes of privatisation or corporatisation 
(Notteboom \& Rodrigue, 2005; Ng \& Pallis, 2010; Sanchez \& Wilmsmeier, 2010; Jacobs \& Notteboom, 2011; Notteboom et al., 2013). The changing role of the port in the transport chain and the greater focus on the individual container terminal rather than the port as a whole have become key issues over recent years (e.g. Slack, 1999; Notteboom \& Winkelmans, 2001; Robinson, 2002; Slack \& Wang, 2002; Slack, 2007), leaving questions regarding the future role to be played by the port authority (Heaver et al., 2000; Olivier and Slack, 2006; Notteboom \& Rodrigue, 2009).

Institutional approaches to port development have argued that the port authority has constraints on its ability to act, stemming from its specific nature. The key distinction is that port development is path dependent, heavily constrained by past actions and institutional design, but also contingent, in relation to private investment and public planning. $\mathrm{Ng}$ and Pallis (2010) showed how port governance is largely determined by local/regional institutional characteristics, despite attempts to implement generic governance solutions. Notteboom et al. (2013) applied the concept of institutional plasticity (Strambach, 2010) to port development, arguing that, while port development is path dependent, a port authority can achieve governance reform by a process of adding layers to existing arrangements. In this way, the port authority does not break from the existing path of development, but develops new capabilities and activities via a process of "institutional stretching". For example, a port authority investing in load centres in the hinterland, beyond their traditional jurisdiction. Jacobs \& Notteboom (2011) asserted the need for an evolutionary perspective, drawing upon the economic geography literature to define the movement from "critical moments" to "critical junctures", concluding that port authorities have "windows of opportunity" in which collective action is possible.

Sanchez and Wilmsmeier (2010) identified the port system as an "autopoietic" system (cf. Maturana and Varela, 1980), meaning that it changes its state with each new input (Schober, 1991), such as time-lagged investments and strategy replication, with the importance of the first mover advantage meaning that a delayed action (e.g. developing a new port to compete with an incumbent) may no longer be suitable due to the new state of the system. Transport autopoiesis is likely to have an especially high inertia when it comes to changing system variables (see Maturana, 1994, p.77; Jantsch, 1982, p.64), due to its "lumpy" or time-lagged investments. In developing countries, autopoiesis may be particularly challenged because of their less flexible and reactive institutions. The autopoietic nature of port system evolution is revealed in how the changing of each input changes the state of the system and can render a 
once-attractive strategy inadvisable if performed too late, once the system has already changed its state. The theory of autopoiesis predicts that when feedback loops are missing, parts of the system may grow in an uncontrollable manner, and, through the limitations of its physical characteristics, may lead to overshooting and collapse of the system. An example of such overshooting and collapse would be ports located close to cities, which, in the age of purpose-built deep-water ports with high capacity inland access, are no longer attractive due to congested landside links and shallower water access. If such ports continue to receive investment, the regional transport system will be inefficient and can have a detrimental effect on the economy. Yet with each transformation of the inputs, the system changes its state (Schober, 1991, p.3520). So, for example, such a port could be kept relevant through institutional support by regulatory bodies and government-backed transport companies.

This characterisation of ports provides an avenue for future research, aiming to determine how institutional adaptations proceed, influenced both by globalised norms (e.g. strategy reproductions by global terminal operators) and regional specificities. More research is needed to identify and classify key factors influencing institutional adaptation within port systems, which, like the factors influencing deconcentration of maritime flows (see Ducruet et al., 2009; Notteboom, 2010; Wilmsmeier \& Monios, 2013), will be a mixture of reactive and proactive.

Thus a more sophisticated institutional appreciation of the port is required, as the entity normally considered a unified port is not only created by numerous actors but is being recreated with each new relationship or network in which the port is embedded. The life cycle theory of the port suggests an inevitable decline after concentration (Charlier, 1992; Schaetzl, 1996; Cullinane and Wilmsmeier, 2011), as mentioned earlier regarding the inversion of concentration through the rise of secondary regional ports. Thus the port's connectivity is always changing and being recreated. Marx believed that the capitalist system carries "within it the seeds of its own destruction" (Marx and Engels, 1850; unpaginated). Perhaps the same logic could be applied to ports as they move through their life cycle, as the symptoms of success (concentration of container flows at a single port) are themselves the cause of congestion, stagnation and decline, if not addressed. The question is how ports should address this problem; drawing on the previous sections of this chapter, it can be seen that institutional complexities can inhibit the ability of actors in the maritime sector to anticipate such structural challenges. 
Recursion can be defined as "the repeated application of a rule, definition, or procedure to successive results" (OED, 2010). This is a useful recasting of autopoiesis because it relates to replication (e.g. copying port development strategies) and enables classification of successful or constrained recursion, recursive relationships, deformed recursion, and so on. As ports and shipping lines have over the last decade consolidated into a handful of global giants, strategies tend to become more generic across the industry, such as global port terminal operator HPH pursuing a strategy of investment in inland terminals in both Europe (i.e. a mature intermodal market) and central America (i.e. an emerging intermodal market). But these applications do not always succeed, leading to incongruent development paths that then subsequently influence other decisions. Taking a mobilities perspective highlights how the physical immobility of transfer points (i.e. ports and intermodal terminals) underpinning global mobility masks an institutional mobility. The institutional environment in which ports are embedded is not static bur rather an ever-changing network of spatial and scalar relations. These can be analysed in terms of both territorial and relational components. For instance, when a global port terminal operator replicates the same strategy across a portfolio of geographically distant ports, the result can be different in each case due to the fact that each port is embedded in its own local and regional territorial and relational hierarchies. Ports thus exhibit both geographical and institutional mobility, corresponding to the geographical and institutional kinds of proximity identified by Hall and Jacobs (2010) and the geographical and institutional kinds of peripherality identified by Monios and Wilmsmeier (2012b).

\section{Applying a systems perspective to material mobilities}

When considered as an autopoietic system, the transport system is cyclical and selfreferring. An actor in such a system (e.g. a port authority considering port expansion or a government planner deciding on approval of such a scheme) may encounter stabilising feedback effects that reduce the desired effects of the intervention. For example, one port expansion project may be mimicked by a competitor in the same port range. But selfstrengthening feedback effects can be over-directed (overshooting the system due to, for example, time-lagged investments as described above) and in consequence lead to more negative than positive effects on the system. Such situations occur in the port sector when several expansions of port capacity come onstream at the same time, leading to overcapacity and price wars that damage the stability of the market. For example, the UK port system has moved from under-capacity that saw some of its transhipment traffic move to the continent to a current situation of over-capacity due to time-lagged investments and long planning 
processes, as well as an unexpected recession occurring after investments were already committed (Wilmsmeier and Monios, 2013). As the transport system contains several subsystems (e.g. modal interfaces) these lead through delaying or accelerating effects to the creation of a complex time dynamic in the system.

Infrastructure enables and shapes mobility. Immobilities are vital and strategic, while mobility is spatial and temporal, but above all material. Immobilities discipline mobility, channel it and define its origins and destinations. Mobility has a tempo and rhythm as well as direction and affinities. The quality of maritime freight mobility has transformed into a key component of competitiveness. Topographic variables such as physical boundaries represent external limits, which provide a level of predictability to freight flows and influence the location of major freight routes. Economic and institutional characteristics and structures define the materiality and structure of mobility, but the quality of mobility is also influenced by anthropocentric variables such as the perception and cognition of system users and decision makers. The mobility of freight in geographical space is thus an epitome of the complex relationships that exist between physical systems, political dimensions and strategies of economic development (Hoyle and Knowles, 1998).

Regarding the system of freight mobility, several qualitative and quantitative determinants for the system's complexity can be identified, such as transport cost, distance, connectivity, number of nodes, balance of flows, GDP per capita, edges in the transport network, efficiency measures of material infrastructure. Characteristics of freight transportation are the degree of heterogeneity among companies, in the patterns of delivered goods, alternatives and flows. This heterogeneity is due to different products being produced (different weights, volumes, densities, viscosities, values, care needs, etc.), different localisation of markets and different market types. Typical also is the heterogeneity of the goods, the stakeholders, and the system's complexity and uncertainty with regard to changes in the economic environment (Patton and Sawicki, 1986).

Applying a system theoretical approach enables a differentiation of complexity between elements and relations (Table 1). 
Table 1: Complexity framework of materials mobility

\begin{tabular}{ccccc}
\hline & Multiplicity & Variety & Ambiguity & Variability \\
\hline $\begin{array}{c}\text { Complexity of } \\
\text { elements }\end{array}$ & Size & Diversity & $\begin{array}{c}\text { Degrees of } \\
\text { freedom }\end{array}$ & Dynamics \\
\hline $\begin{array}{c}\text { Complexity of } \\
\text { relations/flows }\end{array}$ & Coupling degree & Divergence & Fuzziness & Chaos \\
\hline
\end{tabular}

Source: based on Szabo, 2000

Table 1 describes the complexity of freight flows in a twofold manner, beginning with the complexity of elements. Origins and destinations, defined as regions in space, inhabit a variety of characteristics, which in their sum influence freight flow. These include variables of size (population, GDP, area) and diversity (population density, etc.). The complexity of relations is defined by variables defining the material and temporal flows. These include value and volume of transported commodities, balance of trade between regions, number of services, etc.

The dimension of multiplicity is related to the number of elements and flows, such as the number of nodal points in the network and their characteristics as well as the connectivity between nodal points such as number of services in maritime transport. Variety is the expression of multitude in the system, thus referring to the number of available modes of transport, services, and so on. Moreover, it is an expression of the deficit of knowledge of the system. Quality and structure of the system are described with ambiguity, which is linked to the variable aspect of complexity in the dynamic of elements and growth and decline patterns. The uncertainty in interaction in time is described with the term of chaos, because it is impossible to predict.

\section{Conclusion}

This chapter analysed the complexities of the maritime and port systems, identifying and exploring the challenges to synchronizing maritime networks and demand, as revealed through processes of concentration and deconcentration and centralisation and decentralisation. Applying a mobilities perspective has allowed the identification and definition of productive, unproductive and induced material mobilities. The findings deepen understanding of the recursive relationship between the mobile (shipping networks) and the 
immobile (ports), providing tools to understand the spatio-temporal evolution of maritime freight mobility. The institutional adaptations of port actors in recent years enables identification of both geographical and institutional mobility, which builds on previous theoretical work by corresponding to the geographical and institutional kinds of proximity identified by Hall and Jacobs (2010) and the geographical and institutional kinds of peripherality identified by Monios and Wilmsmeier (2012b).

Recognising the maritime and port systems as autopoietic facilitates the tracking of recursive global strategies that emerge through time-lagged investments and local and regional specificities. These can result in a certain uncontrollable aspect to port system evolution, due to missing feedback loops that sometimes lead to overshooting of the system and exacerbating unproductive mobilities. Finally, adopting a systems perspective provides the conceptual grounding to begin to classify and categorise the key elements and flows in the material mobilities system, which provide the basis for future research. In particular, this perspective can be used in future to explore threats to the current system of global shipping, such as fuel shortages and price rises, increased regulation of emissions (e.g. new sulphur control zones), less need for transport due to new forms of manufacturing (e.g. 3D printing) or a shift in production locations from Asia to other emerging economies.

\section{References}

Alphaliner. (2012). Evolution of carriers fleets. Available at: http://www.alphaliner.com/liner2/research_files/liner_studies/misc/AlphalinerTopCarrier s-2012.pdf Accessed 25th September 2013.

Amin, A. (2004). Regions unbound: Towards a new politics of place. Geografiska Annaler, Series B Human Geography, 86, 33-44.

Amin, A., Thrift, N. (2002). Cities: Reimagining the Urban. Cambridge: Polity Press.

Barke, M. (1986). Transport and Trade; Conceptual Frameworks in Geography. Edinburgh: Oliver \& Boyd.

Bergqvist, R., Falkemark, G., Woxenius, J. (2010). Establishing intermodal terminals. World Review of Intermodal Transportation Research. 3 (3): 285-302.

Bird, J. (1963). The Major Seaports of the United Kingdom. London: Hutchinson \& Co.

Brenner, N. (1998). Between fixity and motion: Accumulation, territorial organization and the historical geography of spatial scales. Environment and Planning D: Society and Space, 16, 459-481. 
Charlier, J. (1992). The regeneration of old port areas for new port users. In: B. S. Hoyle \& D. A. Pinder (Eds). European port cities in transition. London: Belhaven Press.

Christaller, W. (1933). Die Zentralen Orte in Süddeutschland (Central Places in Southern Germany). Trans. C. W. Baskin (1966). Englewood Cliffs, NJ: Prentice Hall.

Cullinane, K. P. B., Khanna, M. (2000). Economies of scale in large containerships: optimal size and geographical implications. Journal of Transport Geography, 8, 181-195.

Cullinane, K. P. B., Wang, Y. (2012). The hierarchical configuration of the container port industry: an application of multiple linkage analysis. Maritime Policy \& Management. 39 (2): 169-187.

Cullinane, K. P. B., Wilmsmeier, G. (2011). The Contribution of the Dry Port Concept to the Extension of Port Life Cycles. In: Böse, J. W. (Ed.). Handbook of Terminal Planning. New York, Springer, pp.359-380.

Debrie, J., Lavaud-Letilleul, V., Parola, F. (2013). Shaping port governance: the territorial trajectories of reform. Journal of Transport Geography. 27: 56-65.

DfT. (2012). Port Statistics. Available at: https://www.gov.uk/government/statistical-datasets/port01-uk-ports-and-traffic Accessed 29th May 2013.

Drewry Shipping Consultants. (2012a). Container Market - 2012/13. Annual Review and Forecast. London: Drewry publishing.

Drewry Shipping Consultants. (2012b). Global Container Terminal Operators Annual Review and Forecast 2012. London: Drewry Publishing.

Ducruet, C., Roussin, S., Jo, J-C. (2009). Going west? Spatial polarization of the North Korean port system. Journal of Transport Geography. 17 (5): 357-368.

Ezcurra, R., and Rodríguez-Pose, A. (2013). Political decentralization, economic growth and regional disparities in the OECD. Regional Studies 47(3): 388-401.

Fleming, D. K., Hayuth, Y. (1994). Spatial characteristics of transportation hubs: centrality and intermediacy. Journal of Transport Geography. 2 (1): 3-18.

Frémont, A., Soppé, M. (2007). Northern European range: shipping line concentration and port hierarchy. In: Wang, J., Olivier, D., Notteboom, T., Slack, B. (Eds). Ports, Cities and Global Supply Chains. Aldershot: Ashgate, pp.105-120.

Graham, M. G. (1998). Stability and competition in intermodal container shipping: finding a balance. Maritime Policy \& Management. 25 (2): 129-147. 
Hall, P. V., Jacobs, W. (2010). Shifting proximities: the maritime ports sector in an era of global supply chains. Regional Studies. 44 (9): 1103-1115.

Hall, P., Hesse, M., Rodrigue, J-P. (2006). Reexploring the interface between economic and transport geography. Environment \& Planning A. 38 (7): 1401-1408.

Harvey, D. (1981). The spatial fix - Hegel, Von Thunen and Marx. Antipode. 13 (3): 1-12.

Harvey D. (1982). The Limits to Capital. Oxford: Blackwell

Hayuth, Y. (1981). Containerization and the load center concept. Economic Geography. 57 (2): 160-176.

Heaver, T., Meersman, H., Moglia, F., Van de Voorde, E. (2000). Do mergers and alliances influence European shipping and port competition? Maritime Policy \& Management. 27 (4): 363-373.

Hesse, M. (2008). The City as a Terminal. Logistics and Freight Distribution in an Urban Context. Aldershot: Ashgate

Hesse, M. (2013). Cities and flows: re-asserting a relationship as fundamental as it is delicate. Journal of Transport Geography. 29: 33-42.

Hesse, M., Rodrigue, J-P. (2004). The transport geography of logistics and freight distribution. Journal of Transport Geography. 12 (3): 171-184.

Hotelling, H. (1929). Stability in competition. Economic Journal. 39 (153): 41-57.

Hoyle, B. S. (1968). East African seaports: an application of the concept of 'anyport'. Transactions \& Papers of the Institute of British Geographers. 44: 163-183.

Hoyle, B, Knowles, R. (1998): Modern Transport Geography - Edition 2, Chichester, p. 14 ff.

Jacobs, W., Notteboom, T. (2011). An evolutionary perspective on regional port systems: the role of windows of opportunity in shaping seaport competition. Environment \& Planning A. 43 (7): 1674-1692.

Jantsch, E. (1982). Die Selbstorganisation des Universums. Munich: Hanser.

Lee, S-W., Song, D-W., Ducruet, C. (2008). A tale of Asia's world ports: the spatial evolution in global hub port cities. Geoforum. 39 (1): 372-385

Lösch, A. (1940). Die Räumliche Ordnung der Wirtschaft (The Economics of Location). Trans. W. W. Woglom, W. F. Stolper (1954). New Haven, Conn.: Yale UP.

Martin, C. (2013). Shipping container mobilities, seamless compatibility and the global surface of logistical integration. Environment \& Planning A. 45 (5): 1021-1036. 
Marx, K., Engels, F. (1850). Address of the Central Committee to the Communist League. Available at: http://www.marxists.org/archive/marx/works/1847/communist-league/1850ad1.htm Accessed 16th May 2014.

Maturana, H. R. (1994). Was ist Erkennen? Munich: Piper.

Maturana, H. R., Varela, F. J. (1980). Autopoiesis and Cognition. Dordrecht, Holland: D. Reidel.

Monios, J. (2014). Institutional challenges to intermodal transport and logistics. London: Ashgate.

Monios, J. (2015). Intermodal transport as a regional development strategy: the case of Italian freight villages. Growth and Change. In press.

Monios, J., Wang, Y. (2013). Spatial and institutional characteristics of inland port development in China. GeoJournal. 78 (5): 897-913.

Monios, J., Wilmsmeier, G. (2012a). Giving a direction to port regionalisation. Transportation Research Part A: Policy \& Practice. 46 (10): 1551-1561.

Monios, J., Wilmsmeier, G. (2012b). Port-centric logistics, dry ports and offshore logistics hubs: strategies to overcome double peripherality? Maritime Policy \& Management. 39 (2): 207-226.

Monios, J., Wilmsmeier, G. (2013). The role of intermodal transport in port regionalisation. Transport Policy. 30: 161-172.

Ng, K. Y. A., Cetin, I. B. (2012). Locational characteristics of dry ports in developing economies: some lessons from Northern India. Regional Studies. 46 (6): 757-773.

Ng, K. Y. A., Gujar, G. C. (2009). Government policies, efficiency and competitiveness: the case of dry ports in India. Transport Policy. 16 (5): 232-239.

Ng, A. K. Y., Pallis, A. A. (2010). Port governance reforms in diversified institutional frameworks: generic solutions, implementation asymmetries. Environment \& Planning A. 42 (9): 2147-2167.

Notteboom, T. E. (2005). The peripheral port challenge in container port systems. In: Leggate, H., McConville, J., Morvillo, A. (Eds). International Maritime Transport: Perspectives. London: Routledge, pp. 173-188.

Notteboom, T. (2007). The changing face of the terminal operator business: lessons for the regulator. Paper presented at the ACCC Regulatory Conference. Gold Coast, Australia, July 2007. 
Notteboom, T. E. (2010). Concentration and the formation of multi-port gateway regions in the European container port system: an update. Journal of Transport Geography. 18 (4): 567-583.

Notteboom, T., de Langen, P., Jacobs, W. (2013). Institutional plasticity and path dependence in seaports: interactions between institutions, port governance reforms and port authority routines. Journal of Transport Geography. 27: 26-35.

Notteboom, T. E., Rodrigue, J. (2005). Port regionalization: towards a new phase in port development. Maritime Policy \& Management. 32 (3): 297-313.

Notteboom, T. E., Rodrigue, J-P. (2009). Inland terminals within North American \& European Supply Chains. In: Transport and Communications Bulletin for Asia and the Pacific No. 78: Development of Dry Ports. New York: UNESCAP.

Notteboom, T. E., Winklemans, W. (2001). Structural changes in logistics: how will port authorities face the challenge? Maritime Policy \& Management, 28 (1): 71-89.

Olivier, D., Slack, B. (2006). Rethinking the port. Environment \& Planning A. 38 (8): 14091427.

OED. (2010). Oxford Dictionary of English. $3^{\text {rd }}$ ed. Oxford University Press: Oxford.

Panayides, P. M. (2006). Maritime logistics and global supply chains: towards a research agenda. Maritime Economics \& Logistics. 8 (1): 3-18.

Patton, CV., Sawicki, D.S. (1986): Basic methods of policy analysis and planning, Prentice Hall, Englewood Cliffs.

Rimmer, P. J. (1967). The search for spatial regularities in the development of Australian seaports 1861 - 1961/2. Geograkiska Annaler. 49: 42-54.

Robinson, R. (2002). Ports as elements in value-driven chain systems: the new paradigm. Maritime Policy \& Management. 29 (3): 241-255.

Rodrigue, J-P. (2006). Challenging the derived transport-demand thesis: geographical issues in freight distribution. Environment \& Planning A. 38 (8): 1449-1462.

Rodrigue, J-P. (2013). The repositioning of empty containers. Available at:

http://people.hofstra.edu/geotrans/eng/ch5en/appl5en/ch5a3en.html Accessed 29th May 2013

Rodrigue, J-P., Debrie, J., Fremont, A., Gouvernal, E. (2010). Functions and actors of inland ports: European and North American dynamics. Journal of Transport Geography. 18 (4): 519-529. 
Rodrigue, J-P., Notteboom, T. (2009). The terminalisation of supply chains: reassessing the role of terminals in port/hinterland logistical relationships. Maritime Policy \& Management. 36 (2): 165-183.

Rodrigue, J-P., Notteboom, T. (2010). Comparative North American and European gateway logistics: the regionalism of freight distribution. Journal of Transport Geography. 18 (4): 497-507.

Rodríguez-Pose, A., and Fratesi, U. (2004) Between development and social policies: the impact of European Structural Funds in Objective 1 regions. Regional Studies 38(1): 97113.

Roser, G., Russell, K. Wilmsmeier, G. and Monios, J. (2013). Integrating ports and hinterlands - a Scottish perspective from shop floor. In: Bergqvist, R., Wilmsmeier, G., Cullinane, K.P.B. (Eds.). Dry ports - A Global Perspective: Challenges and Developments in Serving Hinterlands. Farnham: Ashgate

Roso, V., Woxenius, J., Lumsden, K. (2009). The dry port concept: connecting container seaports with the hinterland. Journal of Transport Geography. 17 (5): 338-345.

Sánchez RJ and Perrotti DE. (2012). Looking into the future: big full containerships and their arrival to South American ports. Maritime Policy and Management, Volume 39, Issue 6, 2012.

Sanchez, RJ and Wilmsmeier, G. (2006). The river plate basin - A comparison of port devolution processes on the East Coast of South America. Research in Transportation Economics, 17: 185-205.

Sánchez, R., Wilmsmeier, G. (2010). Contextual Port Development: A Theoretical Approach. In: Coto-Millán, P., Pesquera, M., Castanedo, J. (Eds). Essays on Port Economics. New York: Springer, pp. 19-44.

Schaetzl, L. (1996). Wirtschaftsgeographie 1 - Theorie. 6th ed. Paderborn: UTB.

Schober, H. (1991). Irritation und Bestätigung - Die Provokation der systemischen Beratung oder: Wer macht eigentlich die Veränderung? In: Hofmann, M. (Ed.). Theorie und Praxis der Unternehmensberatung. Heidelberg: Physica, pp.345-370.

Sheller, M., Urry, J. (2006). The new mobilities paradigm. Environment \& Planning A. 38 (2): 207-226.

Slack, B. (1999). Satellite terminals: a local solution to hub congestion? Journal of Transport Geography. 7 (4): 241-246. 
Slack, B. (2007). The terminalisation of seaports. In: Wang, J., Olivier, D., Notteboom, T., Slack, B. (Eds). Ports, Cities and Global Supply Chains. Aldershot: Ashgate, pp.41-50.

Slack, B., Frémont, A. (2005). Transformation of port terminal operations: from the local to the global. Transport Reviews. 25 (1): 117-130.

Slack, B., Wang, J. J. (2002). The challenge of peripheral ports: an Asian perspective. GeoJournal. 56 (2): 159-166.

Song, D-W., Panayides, P. M. (2008). Global supply chain and port/terminal: integration and competitiveness. Maritime Policy \& Management. 35 (1): 73-87.

Strambach, S. (2010). Path dependency and path plasticity: the co-evolution of institutions and innovation - the German customised business software industry. In: Boschma, R., Martin, R. (Eds). Handbook of Evolutionary Economic Geography. Cheltenham, Edward Elgar, pp. 406-431.

Swyngedouw, E. (1992). Territorial organization and the space/technology nexus. Transactions of the Institute of British Geographers. 17 (4): 417-433.

Szabo, O. (2000). Die Gestaltung “nachhaltiger” ÖPNV-Netzwerke mit dem Transaktionskostenansatz. Zeitschrift für Verkehrswissenschaft. 1: 1-39.

Taaffe, E. J., Morrill, R. L., Gould, P. R. (1963). Transport expansion in underdeveloped countries: a comparative analysis. Geographical Review. 53: 503-529.

Theofanis, S., Boile, M. (2009). Empty marine container logistics: facts, issues and management strategies. Geojournal. 74 (1): 51-65.

UNCTAD. (2009). Review of Maritime Transport. Geneva: UNCTAD.

Van de Voorde, E., Vanelslander, T. (2009). Market power and vertical and horizontal integration in the maritime shipping and port industry. JTRC OECD/ITF Discussion Paper 2009-2. Paris: ITF.

Van Klink, H. A. (1998). The port network as a new stage in port development: the case of Rotterdam. Environment and Planning A. 30 (1): 143-160.

Von Thünen, J. H. (1826). Der Isolierte Staat (The Isolated State). Trans. C. M. Wartenberg (1966). Oxford: Pergamon.

Wang, J. J., Ng, A. K. Y. 2011. The geographical connectedness of Chinese seaports with foreland markets: a new trend? Tijdschrift voor Economische en Sociale Geografie. 102 (2): 188-204.

Weber, A. (1909). Über den Standort der Industrien (Theory of the Location of Industries). Trans. C. J. Friedrich (1929). Chicago: The University of Chicago Press. 
Wilmsmeier, G., Monios, J. (2013). Counterbalancing peripherality and concentration: an analysis of the UK container port system. Maritime Policy \& Management. 40 (2): 116132.

Wilmsmeier, G., Monios, J., Pérez-Salas, G. (2014). Port system evolution: the case of Latin America and the Caribbean. Journal of Transport Geography. 39: 208-221.

Wilmsmeier, G., Notteboom, T. (2011). Determinants of liner shipping network configuration: a two-region comparison. GeoJournal. 76 (3): 213-228.

Wilmsmeier, G., Parushev, T. (2013). Liner shipping industry - evolution, stability and concentration in South American markets. UN-ECLAC working paper.

Wilmsmeier, G., Monios, J., Lambert, B. (2010). Observations on the regulation of "dry ports" by national governments. Paper presented at the annual conference of the International Association of Maritime Economists (IAME), Lisbon, July 2010.

Wilmsmeier, G., Monios, J., Lambert, B. (2011). The directional development of intermodal freight corridors in relation to inland terminals. Journal of Transport Geography. 19 (6): 1379-1386. 